\title{
PENGGUNAAN METODE DECISION TREE UNTUK MENDETEKSI KETERLAMBATAN MASA STUDI MAHASISWA DIPERGURUAN TINGGI BREBES
}

\author{
Nur Ariesanto Ramdhan, Abdul Khamid \\ Fakultas Teknik Universitas Muhadi Setiabudi (UMUS) Brebes, Jawa Tengah, \\ Indonesia \\ Email: ariesantoramdhan@gmail.com, abdulkhamid.mt@gmail.com
}

\begin{abstract}
Abstrak
Keberhasilan masa studi dalam pengelolaan suatu akademik diperguruan Tinggi salah satu diantaranya adalah ketepatan mahasiswa dalam menempuh studinya. Masih banyaknya mahasiswa yang tidak lulus tepat waktu merupakan masalah yang serius bagi suatu perguruan tinggi. Mengetahui permasalahan itu diperlukan pengolahan data akademik untuk mendapatkan pola atau pengetahuannya untuk mengambil suatu keputusan. Melalui Educational Data Mining (EDM) merupakan penerapan metode Datamining dalam menganalisis data yang tersedia dan dapat digunakan sebagai salah satu pendekatan yang dapat dilakukan. Melalui data akademik kelulusan pada mahasiswa Program Studi Teknik Sipil Universitas Muhadi Setiabudi dapat diperoleh suatu pohon keputusan beserta aturannya untuk dapat memprediksi masa studi mahasiswa, data yang digunakan untuk merancang pohon keputusan ini terdiri dari 1 special atribut (atribut kelulusan) dan 12 atribut regular (JK, status kerja, umur, IPS1, IPS2, IPS3, IPS4, IPS5, IPS6, IPS7, IPS8, IPK). Dalam membuat analisa data menggunakan Algoritma C4.5 dengan menggunakan 77 sampel, dari hasil yang didapatkan terlihat bahwa model keputusan dengan siswa yang dalam lulus tepat waktu adalah mahasiswa yang memiliki tingkat nilai akurasi sebanyak $98.00 \%$, dengan presisi terlambat $95.45 \%$ dan tepat $100 \%$, Class recall terlambat $100 \%$, dan recall tepat $96.55 \%$. Pengujian dengan rapidminer terbukti efektif dan fleksibel dengan hasil perhitungan yang tepat.
\end{abstract}

Kata Kunci: masa studi mahasiswa; data mining; algoritma C4.5; pohon keputusan.

\section{Abstract}

One of the successes study periods in the management of an academic university is the students' accuracy in taking their studies. There are still many students who do not graduate on time is a serious problem for a university. Knowing the problem requires processing academic data to get the pattern or knowledge to make a decision. Educational Data Mining (EDM) is an application of the Datamining method in analyzing the available data and can be used as one approach that can be done. Through graduation, academic data on students of the Civil Engineering Study Program, Muhadi Setiabudi University, a decision tree, and its rules can be

$\begin{array}{ll}\text { How to cite: } & \text { Ramadhan. N. A \& Khamid, A., (2021) Penggunaan Metode Decision Tree untuk Mendeteksi Keterlambatan } \\ & \text { Masa Studi Mahasiswa Diperguruan Tinggi Brebes. Syntax Literate: Jurnal Ilmiah Indonesia, 6(10). } \\ & \text { http://dx.doi.org/10.36418/ Syntax-Literate.v6i10.4367 } \\ \text { E-ISSN: } & \text { 2548-1398 } \\ \text { Published by: } & \text { Ridwan Institute }\end{array}$


obtained to predict the student's study period, and the data used to design this decision tree consists of 1 special attribute (graduation attribute) and 12 regular attributes (JK, working status, age, IPS1, IPS2, IPS3, IPS4, IPS5, IPS6, IPS7, IPS8, GPA). In making data analysis using the C4.5 Algorithm using 77 samples, the results obtained show that the decision model with students who graduate on time are students who have an accuracy value of $98.00 \%$, with $95.45 \%$ late precision and $100 \%$ correct, Class recall is $100 \%$ late, and recall is appropriate $96.55 \%$. Testing with rapid miner is proven to be effective and flexible with precise calculation results.

Keywords: studies; data mining; algorithm C4.5; Decision tree

Received: 2021-09-20; Accepted: 2021-10-05; Published: 2021-10-20

\section{Pendahuluan}

Perkembangan teknologi informasi yang begitu maju sangat di butuhkan dalam menentukan suatu keputusan, hal ini menjadikan informasi sebagai suatu sarana untuk menganalisa. Dalam menganalisa diperlukan suatu data sebagai bahan pertimbangan dari informasi (Sutabri, 2012). Dengan menggunakan data mining kumpulan data dapat memberikan informasi yang penting bagi suatu organisasi. Perguruan tinggi dengan jumlah mahasiswa yang banyak harus dapat dimbangi dengan kualitas sistem pendidikan yang diberikan kepada mahasiswa. Salah satu faktor yang menentukan kualitas perguruan tinggi adalah persentase kemampuan mahasiswa untuk menyelesaikan masa studi secara tepat waktu. Tingginya persentasi mahasiswa yang tidak mampu menyelesaikan masa studinya secara tepat waktu maka akan menyebabkan berbagai masalah yang berkaitan dalam kegagalan studi mahasiswa seperti meningkatnya status mahasiswa non aktif di lingkungan perguruan tinggi (Rismayanti, 2018). Hal ini penting untuk meningkatkan pelayanan yang dapat membuat mahasiswa nyaman dan bisa lulus tepat waktu. Penggunaan data mining dapat digunakan sebagai bahan pertimbangan dalam mengambil keputusan lebih lanjut tentang faktor yang mempengaruhi kelulusan mahasiswa dalam menyelesaikan masa studi secara tepat waktu sehingga dapat mencegah secara dini kegagalan akademik mahasiswa (Nofriansyah, Kom, \& Kom, 2015).

Datamining merupakan suatu cara dalam menggali informasi dari sejumlah data yang biasanya tersimpan dalam repositori dengan menggunakan teknologi pengenalan pola, statistik dan teknik matematika (Siregar, Kom, Puspabhuana, Kom, \& Kom, 2017). Penerapan metode datamining dalam menganalisis data yang tersedia di lembaga pendidikan didefinisikan sebagai Educational Data Mining (EDM) (Romero \& Ventura, 2010) EDM menggunakan beberapa teknik seperti Decision Trees, Neural Networks, Nä̈ve Bayes, K-Nearest Neighbor dan lainnya (Yadav \& Pal, 2012). Pengetahuan yang didapatkan dari pengolahan datamining dapat digunakan untuk menawarkan suatu rekomendasi kepada perencana akademik di lembaga pendidikan tinggi dalam meningkatkan proses pengambilan keputusan (decision making), meningkatkan kinerja akademik dan memangkas tingkat kegagalan siswa serta lebih memahami perilaku para 
siswa (Abu Tair \& El-Halees, 2012). Hal tersebut merupakan tujuan yang ingin dicapai dalam pemanfaatan data mining di bidang pendidikan.

Penelitian mengenai data mining pada lembaga pendidikan telah banyak dilakukan oleh para peneliti. Algoritma C4.5 merupakan algoritma klasifikasi pohon keputusan yang banyak digunakan karena memiliki kelebihan utama dari algoritma yang lainnya (Kamagi \& Hansun, 2014). Kelebihan algoritma C4.5 dapat menghasilkan pohon keputusan yang mudah diinterprestasikan memiliki tingkat akurasi yang dapat diterima, efisien, dalam menangani atribut bertipe deskret dan numerik. Metode data mining dengan algoritma C45 merupakan salah satu algoritma yang digunakan untuk melakukan klasifikasi atau segmentasi atau pengelompokan dan bersifat prediktif (Rosandy, 2016). Klasifikasi merupakan salah satu proses pada datamining yang bertujuan untuk menemukan pola yang berharga dari data yang berukuran relatif besar hingga sangat besar (Harianto \& Rosiyadi, 2020). Pada penelitian ini algoritma C4.5 diusulkan untuk memprediksi masa studi mahasiswa di perguruan tinggi wilayah Brebes (Rahman, 2020). Tujuan penelitian ini adalah untuk mengetahui prediksi masa studi mahasiswa di Universitas Muhadi Setia Budi Brebes.

\section{Metode Penelitian}

Metode penelitian yang dilakukan adalah metode penelitian eksperimen (Jaedun, 2011). Data dikumpulkan ialah data identitas mahasiswa dan data KRS, selanjutnya diolah (preprocessing) dengan penerapan data integrasi dan data reduction, metode menggunakan decission tree dengan algoritma C4.5 pengujian dilakukan dengan menggunakan sebagian data untuk training dan sebagian lagi evaluasi dilakukan dengan mengamati hasil prediksi menggunakan algoritma $\mathrm{C} 4.5$ dan validasi dilakukan dengan mengukur hasil prediksi dibandingkan dengan data asal.

\section{Hasil dan Pembahasan}

Masa studi adalah masa atau lamanya studi yang terjadwal dan harus dijalankan oleh mahasiswa dengan rentang waktu yang disyaratkan dengan beban sks yaitu 144 sks, dengan rentang waktu 8 semester normalnya dan selambatnya 14 semester. Namun masa studi mahasiswa tidak bisa diprediksi sejak awal, oleh karena itu perlu adanya teknik prediksi dengan menggunakan metode Decision tree dengan algoritma C4.5. Hasil pre-processing pada penelitian ini menggunakan dua langkah pre-processing yaitu data intergration dan reduction.

1. Data Integration (proses penggabungan dari database yang berbeda)

Data set pada peneltian ini adalah database TS angkatan 2014-2015 dan 20152016.

2. Data reduction

Mereduksi atau menghilangkan atribut yang tidak diperlukan akan tetapi tidak mengurangi penyajian analistiknya. Berikut data integration dan hasil reduksi data yang telah dilakukan dengan menggunakan Software Rapidminer. 


\section{Tabel 1}

Data Awal Mahasiswa

\begin{tabular}{|c|c|c|c|c|c|c|c|c|c|c|c|c|c|}
\hline ID & JK & $\begin{array}{l}\text { STATUS } \\
\text { KERJA }\end{array}$ & UMUR & $\begin{array}{c}\text { IPS } \\
1\end{array}$ & $\begin{array}{c}\text { IPS } \\
2 \\
\end{array}$ & $\begin{array}{c}\text { IPS } \\
3\end{array}$ & $\begin{array}{c}\text { IPS } \\
4 \\
\end{array}$ & $\begin{array}{c}\text { IPS } \\
5\end{array}$ & $\begin{array}{c}\text { IPS } \\
6 \\
\end{array}$ & $\begin{array}{c}\text { IPS } \\
7 \\
\end{array}$ & $\begin{array}{c}\text { IPS } \\
8 \\
\end{array}$ & IPK & $\begin{array}{c}\text { STATUS } \\
\text { KELULUSAN }\end{array}$ \\
\hline 1 & LAKI-LAKI & BEKERJA & 24 & 2,70 & 2,91 & 1,00 & 1,00 & 1,00 & 1,00 & 1,00 & 0,00 & 1,33 & TERLAMBAT \\
\hline 2 & LAKI-LAKI & BEKERJA & 23 & 2,90 & 3,41 & 3,39 & 3,19 & 2,80 & 3,00 & 3,00 & 0,00 & 2,71 & TEPAT \\
\hline 3 & PEREMPUAN & MAHASISWA & 24 & 3,40 & 3,68 & 3,35 & 3,52 & 3,45 & 3,16 & 3,43 & 0,00 & 3,00 & TEPAT \\
\hline 4 & PEREMPUAN & MAHASISWA & 22 & 3,10 & 3,64 & 3,83 & 3,38 & 3,20 & 2,32 & 3,43 & 0,00 & 2,86 & TEPAT \\
\hline 5 & PEREMPUAN & BEKERJA & 23 & 3,30 & 3,68 & 3,39 & 3,48 & 3,35 & 3,29 & 2,95 & 0,00 & 2,93 & TEPAT \\
\hline 6 & LAKI-LAKI & BEKERJA & 25 & 2,90 & 3,36 & 3,35 & 2,81 & 3,00 & 2,84 & 3,00 & 0,00 & 2,66 & TEPAT \\
\hline 7 & LAKI-LAKI & BEKERJA & 25 & 3,30 & 3,59 & 3,35 & 3,38 & 2,75 & 2,74 & 3,14 & 0,00 & 2,78 & TEPAT \\
\hline 8 & LAKI-LAKI & MAHASISWA & 25 & 2,80 & 3,59 & 1,00 & 1,00 & 1,00 & 1,00 & 1,00 & 0,00 & 1,42 & TERLAMBAT \\
\hline 9 & LAKI-LAKI & MAHASISWA & 24 & 1,80 & 1,00 & 1,00 & 1,00 & 1,00 & 1,00 & 1,00 & 0,00 & 0,98 & TERLAMBAT \\
\hline 10 & LAKI-LAKI & MAHASISWA & 25 & 3,20 & 3,27 & 3,13 & 3,00 & 2,50 & 2,84 & 3,29 & 0,00 & 2,65 & TERLAMBAT \\
\hline 11 & LAKI-LAKI & MAHASISWA & 25 & 3,00 & 3,45 & 3,30 & 2,90 & 3,05 & 3,11 & 3,29 & 0,00 & 2,76 & TERLAMBAT \\
\hline 12 & PEREMPUAN & BEKERJA & 25 & 3,20 & 3,77 & 3,26 & 3,43 & 2,70 & 3,11 & 3,00 & 0,00 & 2,81 & TEPAT \\
\hline 13 & PEREMPUAN & BEKERJA & 23 & 3,10 & 3,50 & 3,35 & 3,38 & 3,15 & 3,11 & 3,29 & 0,00 & 2,86 & TEPAT \\
\hline 14 & PEREMPUAN & MAHASISWA & 24 & 1,00 & 1,00 & 1,00 & 1,00 & 1,00 & 1,00 & 1,00 & 0,00 & 0,88 & TERLAMBAT \\
\hline 15 & LAKI-LAKI & BEKERJA & 23 & 2,90 & 3,14 & 2,91 & 3,05 & 3,00 & 3,00 & 3,57 & 0,00 & 2,70 & TEPAT \\
\hline 16 & LAKI-LAKI & BEKERJA & 23 & 2,90 & 3,05 & 2,52 & 2,90 & 2,90 & 3,00 & 3,29 & 0,00 & 2,57 & TERLAMBAT \\
\hline 17 & LAKI-LAKI & BEKERJA & 24 & 3,00 & 3,25 & 3,00 & 3,05 & 2,85 & 3,00 & 3,00 & 0,00 & 2,64 & TEPAT \\
\hline 18 & LAKI-LAKI & BEKERJA & 25 & 2,90 & 2,23 & 2,36 & 2,50 & 1,00 & 1,00 & 1,00 & 0,00 & 1,62 & TERLAMBAT \\
\hline 19 & LAKI-LAKI & MAHASISWA & 25 & 2,50 & 2,36 & 1,00 & 1,00 & 1,00 & 1,00 & 1,00 & 0,00 & 1,23 & TERLAMBAT \\
\hline 20 & LAKI-LAKI & BEKERJA & 28 & 3,40 & 3,59 & 3,78 & 3,71 & 3,45 & 2,79 & 3,43 & 0,00 & 3,02 & TEPAT \\
\hline 21 & PEREMPUAN & BEKERJA & 25 & 2,80 & 3,00 & 3,26 & 3,14 & 3,00 & 2,79 & 3,29 & 0,00 & 2,66 & TEPAT \\
\hline 22 & LAKI-LAKI & BEKERJA & 24 & 2,70 & 3,50 & 3,35 & 3,29 & 2,95 & 3,16 & 3,14 & 0,00 & 2,76 & TEPAT \\
\hline 23 & LAKI-LAKI & MAHASISWA & 25 & 3,00 & 3,18 & 3,13 & 2,90 & 2,85 & 3,00 & 3,00 & 0,00 & 2,63 & TEPAT \\
\hline 24 & LAKI-LAKI & BEKERJA & 26 & 2,90 & 1,59 & 3,00 & 3,19 & 2,90 & 2,53 & 3,14 & 0,00 & 2,41 & TERLAMBAT \\
\hline 25 & LAKI-LAKI & MAHASISWA & 23 & 3,00 & 3,41 & 3,26 & 3,48 & 3,25 & 3,26 & 3,17 & 0,00 & 2,85 & TEPAT \\
\hline 26 & PEREMPUAN & BEKERJA & 22 & 2,90 & 3,59 & 3,35 & 3,14 & 3,10 & 3,11 & 3,43 & 0,00 & 2,83 & TEPAT \\
\hline 27 & LAKI-LAKI & BEKERJA & 28 & 3,10 & 3,64 & 3,57 & 3,29 & 3,10 & 3,11 & 3,43 & 0,00 & 2,91 & TEPAT \\
\hline 28 & LAKI-LAKI & BEKERJA & 24 & 3,20 & 3,82 & 3,26 & 3,43 & 3,15 & 3,00 & 3,29 & 0,00 & 2,89 & TEPAT \\
\hline 29 & PEREMPUAN & BEK & 24 & 3,00 & 3,77 & 3,48 & 3,48 & 3,35 & 2,63 & 3,43 & 0,00 & 2,89 & TEPAT \\
\hline 30 & LAKI-LAKI & BEKERJA & 30 & 2,50 & 3,41 & 3,35 & 3,05 & 2,90 & 2,89 & 3,00 & 0,00 & 2,64 & TEPAT \\
\hline 31 & LAKI-LAKI & MAHASISWA & 25 & 2,90 & 2,77 & 1,00 & 1,00 & 1,00 & 1,00 & 1,00 & 0,00 & 1,33 & TERLAMBAT \\
\hline 32 & LAKI-LAKI & MAHASISWA & 24 & 0,50 & 2,32 & 1,00 & 1,00 & 1,00 & 1,00 & 1,00 & 0,00 & 0,98 & TERLAMBAT \\
\hline 33 & LAKI-LAKI & MAHASISWA & 24 & 2,50 & 1,00 & 1,00 & 1,00 & 1,00 & 1,00 & 1,00 & 0,00 & 1,06 & TERLAMBAT \\
\hline 34 & LAKI-LAKI & BEKERJA & 26 & 2,90 & 3,09 & 3,00 & 2,67 & 3,00 & 2,53 & 3,14 & 0,00 & 2,54 & TEPAT \\
\hline 35 & LAKI-LAKI & MAH & 23 & 1,00 & 1,00 & 1,00 & 1,00 & 1,00 & 1,00 & 1,00 & 0,00 & 0,88 & TERLAMBAT \\
\hline 36 & LAKI-LAKI & BEKERJA & 25 & 2,80 & 2,64 & 0,65 & 2,62 & 3,10 & 1,00 & 1,00 & 0,00 & 1,73 & AMBAT \\
\hline 37 & LAKI-LAKI & BEKERJA & 27 & 3,40 & 3,41 & 3,17 & 2,76 & 3,05 & 2,84 & 3,29 & 0,00 & 2,74 & TEPAT \\
\hline 38 & PEREMPUAN & BEKERJA & 22 & 3,50 & 3,50 & 3,13 & 3,43 & 3,30 & 3,11 & 3,14 & 0,00 & 2,89 & TEPAT \\
\hline 39 & PEREMPUAN & BEKERJA & 22 & 3,50 & 3,50 & 3,22 & 3,24 & 3,45 & 2,79 & 3,29 & 0,00 & 2,87 & TEPAT \\
\hline 40 & LAKI-LAKI & MAHASISWA & 24 & 1,10 & 1,00 & 1,00 & 1,00 & 1,00 & 1,00 & 1,00 & 0,00 & 0,89 & TERLAMBAT \\
\hline 41 & LAKI-LAKI & BEKERJA & 25 & 3,60 & 3,73 & 3,52 & 3,33 & 3,45 & 3,00 & 3,29 & 0,00 & 2,99 & TEPAT \\
\hline 42 & LAKI-LAKI & MAHASISWA & 25 & 2,70 & 2,45 & 1,04 & 0,29 & 1,00 & 1,00 & 1,00 & 0,00 & 1,19 & TERLAMBAT \\
\hline 43 & LAKI-LAKI & BEKERJA & 23 & 3,40 & 3,41 & 3,17 & 3,29 & 3,60 & 3,26 & 3,43 & 0,00 & 2,95 & TEPAT \\
\hline 44 & LAKI-LAKI & BEKERJA & 25 & 3,80 & 3,41 & 3,17 & 2,86 & 3,00 & 2,57 & 2,57 & 0,00 & 2,67 & TEPAT \\
\hline 45 & LAKI-LAKI & MAHASISWA & 24 & 3,30 & 3,59 & 3,00 & 3,00 & 3,10 & 3,00 & 3,00 & 0,00 & 2,75 & TEPAT \\
\hline 46 & PEREMPUAN & MAHASISWA & 24 & 3,80 & 2,91 & 2,78 & 0,48 & 1,00 & 1,00 & 1,00 & 0,00 & 1,62 & TERLAMBAT \\
\hline 47 & LAKI-LAKI & MAHASISWA & 24 & 2,70 & 2,73 & 0,65 & 0,29 & 1,00 & 1,00 & 1,00 & 0,00 & 1,17 & TERLAMBAT \\
\hline 48 & LAKI-LAKI & BEKERJA & 26 & 2,20 & 3,27 & 3,00 & 3,33 & 3,40 & 2,89 & 3,43 & 0,00 & 2,69 & TEPAT \\
\hline 49 & LAKI-LAKI & MAHASISWA & 24 & 3,50 & 3,23 & 2,96 & 0,29 & 1,00 & 1,00 & 2,29 & 0,00 & 1,78 & TERLAMBAT \\
\hline 50 & LAKI-LAKI & MAHASISWA & 24 & 3,53 & 2,14 & 0,65 & 1,00 & 1,00 & 1,00 & 1,00 & 0,00 & 1,29 & TERLAMBAT \\
\hline 51 & LAKI-LAKI & BEKERJA & 25 & 3,60 & 3,23 & 3,00 & 2,82 & 3,10 & 2,74 & 2,86 & 0,00 & 2,67 & \\
\hline 52 & LAKI-LAKI & BEKERJA & 23 & 3,00 & 3,32 & 3,00 & 2,82 & 3,20 & 2,32 & 3,00 & 0,00 & 2,58 & \\
\hline 53 & LAKI-LAKI & BEKERJA & 22 & 3,60 & 3,36 & 3,22 & 3,05 & 3,30 & 3,00 & 3,00 & 0,00 & 2,82 & \\
\hline 54 & LAKI-LAKI & BEKERJA & 28 & 3,80 & 3,36 & 3,09 & 3,05 & 2,55 & 3,00 & 3,00 & 0,00 & 2,73 & \\
\hline 55 & LAKI-LAKI & MAHASISWA & 37 & 2,40 & 3,18 & 3,09 & 1,59 & 2,85 & 2,00 & 2,14 & 0,00 & 2,16 & \\
\hline 56 & LAKI-LAKI & BEKERJA & 25 & 3,00 & 3,36 & 3,09 & 2,64 & 1,00 & 0,07 & 0,57 & 0,00 & 1,72 & \\
\hline 57 & LAKI-LAKI & MAHASISWA & 23 & 1,00 & 1,00 & 1,00 & 1,00 & 1,00 & 1,00 & 1,00 & 0,00 & 0,88 & \\
\hline 58 & LAKI-LAKI & BEKERJA & 24 & 3,80 & 3,32 & 2,91 & 3,14 & 3,10 & 2,16 & 2,86 & 0,00 & 2,66 & \\
\hline 59 & LAKI-LAKI & BEKERJA & 24 & 3,50 & 3,32 & 2,74 & 2,68 & 0,60 & 1,63 & 0,86 & 0,00 & 1,92 & \\
\hline 60 & LAKI-LAKI & MAHASISWA & 23 & 4,00 & 3,36 & 3,00 & 3,27 & 3,35 & 2,05 & 0,06 & 0,00 & 2,39 & \\
\hline 61 & LAKI-LAKI & MAHASISWA & 22 & 3,70 & 3,36 & 3,22 & 3,00 & 2,80 & 2,79 & 2,86 & 0,00 & 2,72 & \\
\hline
\end{tabular}


Penggunaan Metode Decision Tree untuk Mendeteksi Keterlambatan Masa Studi Mahasiswa Diperguruan Tinggi Brebes

\begin{tabular}{|c|c|c|c|c|c|c|c|c|c|c|c|c|c|}
\hline ID & JK & $\begin{array}{c}\text { STATUS } \\
\text { KERJA }\end{array}$ & UMUR & $\begin{array}{c}\text { IPS } \\
1\end{array}$ & $\begin{array}{c}\text { IPS } \\
2\end{array}$ & $\begin{array}{c}\text { IPS } \\
3\end{array}$ & $\begin{array}{c}\text { IPS } \\
4\end{array}$ & $\begin{array}{c}\text { IPS } \\
5\end{array}$ & $\begin{array}{c}\text { IPS } \\
6\end{array}$ & $\begin{array}{c}\text { IPS } \\
7\end{array}$ & $\begin{array}{c}\text { IPS } \\
8\end{array}$ & IPK & $\begin{array}{c}\text { STATUS } \\
\text { KELULUSAN }\end{array}$ \\
\hline 62 & LAKI-LAKI & BEKERJA & 24 & 3,90 & 3,36 & 3,22 & 3,14 & 2,90 & 2,42 & 2,57 & 0,00 & 2,69 & \\
\hline 63 & LAKI-LAKI & MAHASISWA & 29 & 3,80 & 3,36 & 2,74 & 3,41 & 3,20 & 2,42 & 2,71 & 0,00 & 2,71 & \\
\hline 64 & LAKI-LAKI & BEKERJA & 25 & 4,00 & 3,00 & 3,22 & 3,27 & 3,20 & 2,32 & 3,29 & 0,00 & 2,79 & \\
\hline 65 & LAKI-LAKI & BEKERJA & 28 & 3,20 & 2,59 & 2,61 & 2,68 & 2,90 & 3,00 & 2,57 & 0,00 & 2,44 & \\
\hline 66 & LAKI-LAKI & BEKERJA & 26 & 3,50 & 3,45 & 3,09 & 3,27 & 3,10 & 3,13 & 3,14 & 0,00 & 2,84 & \\
\hline 67 & LAKI-LAKI & BEKERJA & 30 & 3,30 & 2,25 & 2,65 & 2,00 & 0,30 & 0,79 & 1,00 & 0,00 & 1,54 & \\
\hline 68 & LAKI-LAKI & BEKERJA & 36 & 2,94 & 1,90 & 3,22 & 3,27 & 3,20 & 2,32 & 3,29 & 0,00 & 2,52 & \\
\hline 69 & LAKI-LAKI & BEKERJA & 38 & 3,00 & 3,00 & 3,00 & 3,00 & 3,50 & 2,82 & 3,14 & 0,00 & 2,68 & \\
\hline 70 & LAKI-LAKI & MAHASISWA & 26 & 4,00 & 3,45 & 3,48 & 3,05 & 3,25 & 3,11 & 3,71 & 0,00 & 3,01 & \\
\hline 71 & LAKI-LAKI & BEKERJA & 27 & 3,00 & 3,00 & 3,00 & 3,00 & 3,60 & 2,91 & 3,16 & 0,00 & 2,71 & \\
\hline 72 & LAKI-LAKI & MAHASISWA & 24 & 0,88 & 1,56 & 2,40 & 1,00 & 0,20 & 1,00 & 1,00 & 0,00 & 1,01 & \\
\hline 73 & LAKI-LAKI & MAHASISWA & 27 & 0,10 & 1,00 & 1,00 & 1,00 & 1,00 & 1,00 & 1,00 & 0,00 & 0,76 & \\
\hline 74 & LAKI-LAKI & BEKERJA & 45 & 3,60 & 3,36 & 3,09 & 2,73 & 2,65 & 2,26 & 2,96 & 0,00 & 2,58 & \\
\hline 75 & LAKI-LAKI & BEKERJA & 26 & 3,00 & 3,00 & 3,00 & 3,00 & 3,60 & 2,91 & 3,16 & 0,00 & 2,71 & \\
\hline 76 & LAKI-LAKI & BEKERJA & 27 & 3,50 & 3,45 & 3,09 & 3,27 & 3,10 & 3,13 & 3,14 & 0,00 & 2,84 & \\
\hline 77 & LAKI-LAKI & BEKERJA & 26 & 3,00 & 3,00 & 3,00 & 3,00 & 3,60 & 2,91 & 3,16 & 0,00 & 2,71 & \\
\hline
\end{tabular}

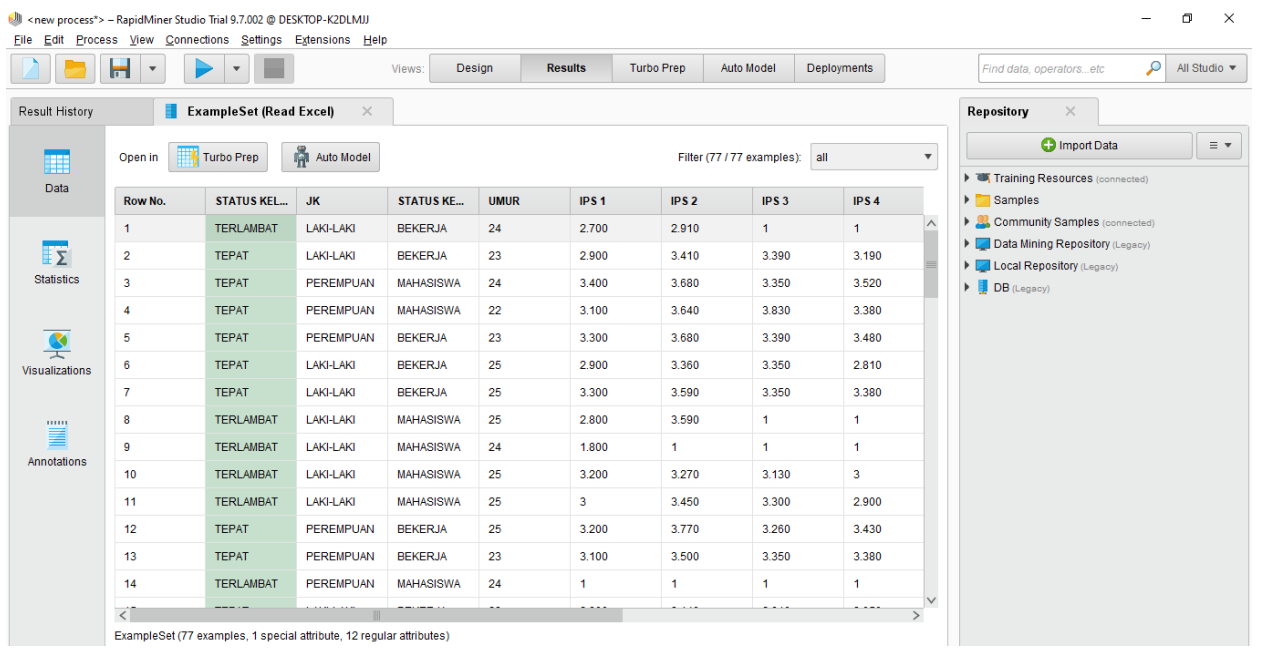

\section{Gambar 1}

Mengimport data kelulusan dari excel

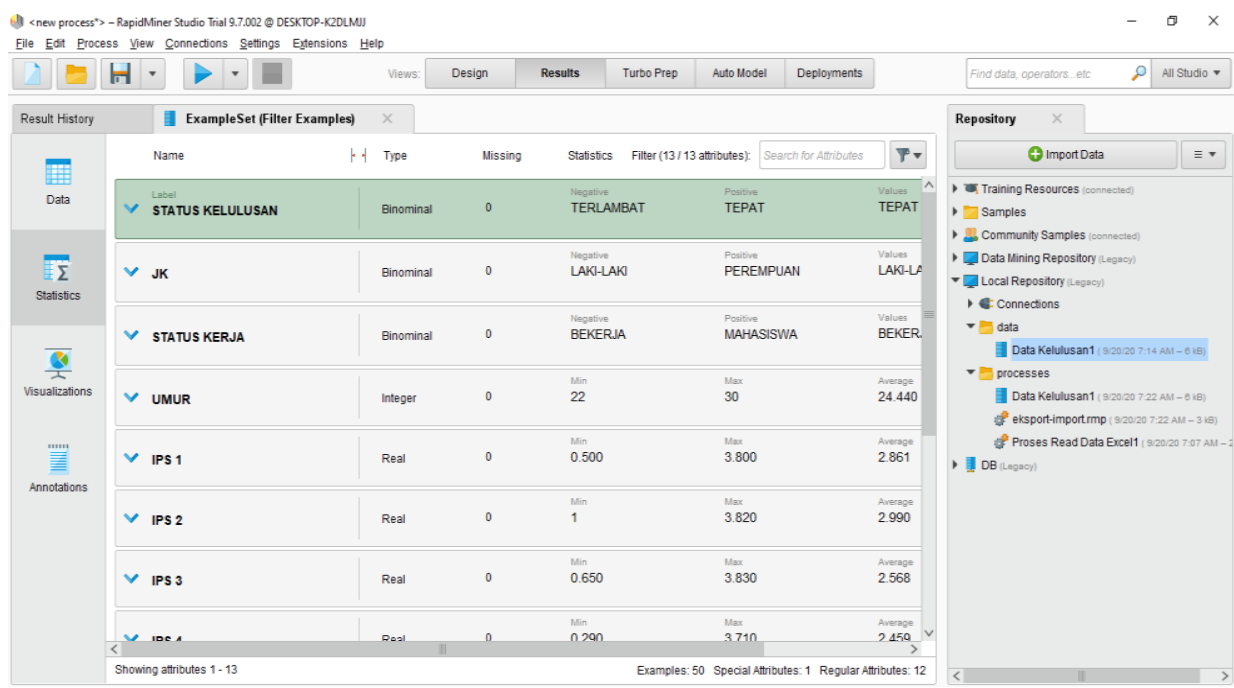

\section{Gambar 2}

Memfilter data setting yang missing dan Data Statastik 


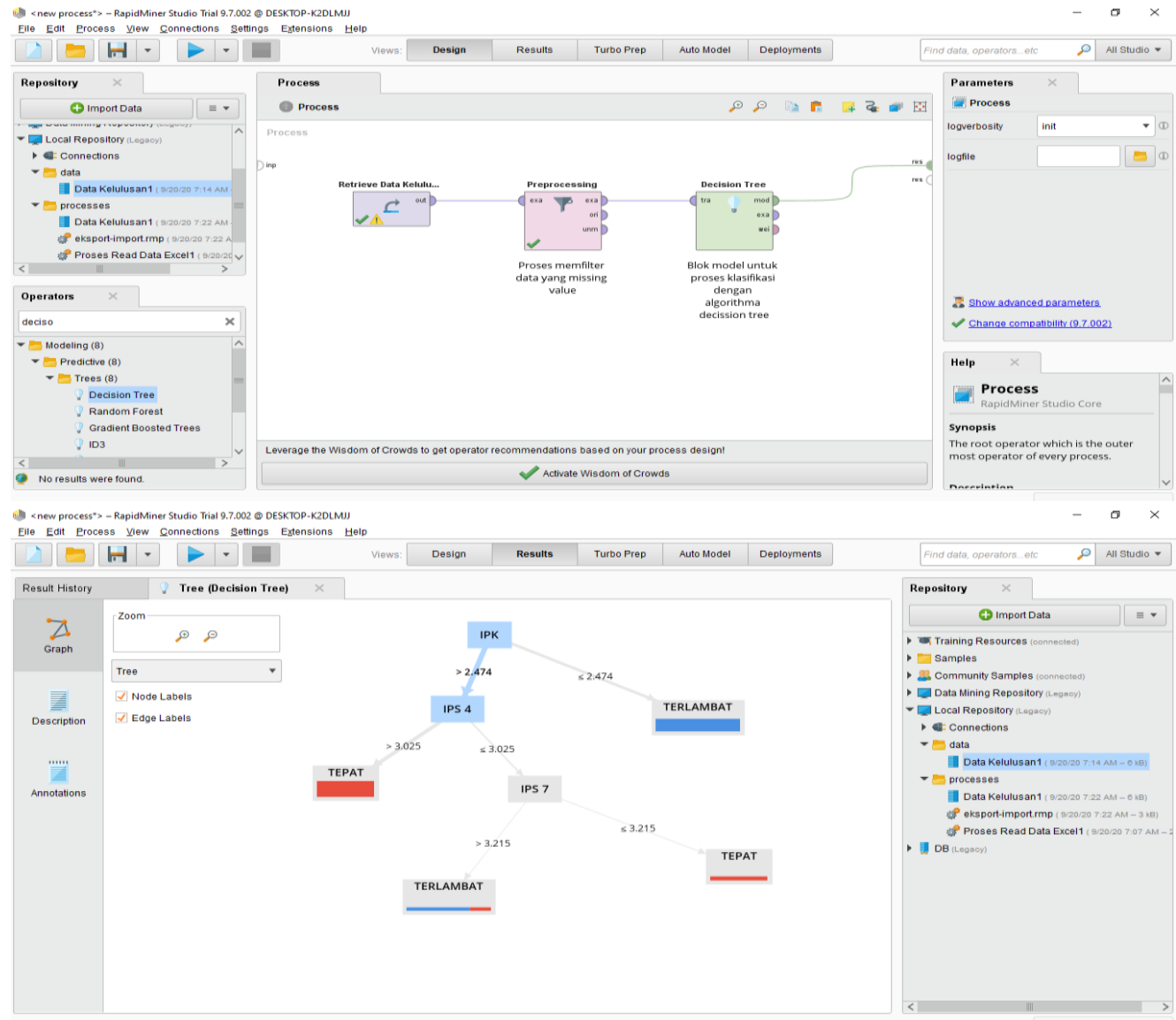

Gambar 3

Pohon keputusan algoritma decesion tree $\mathrm{C} 4.5$

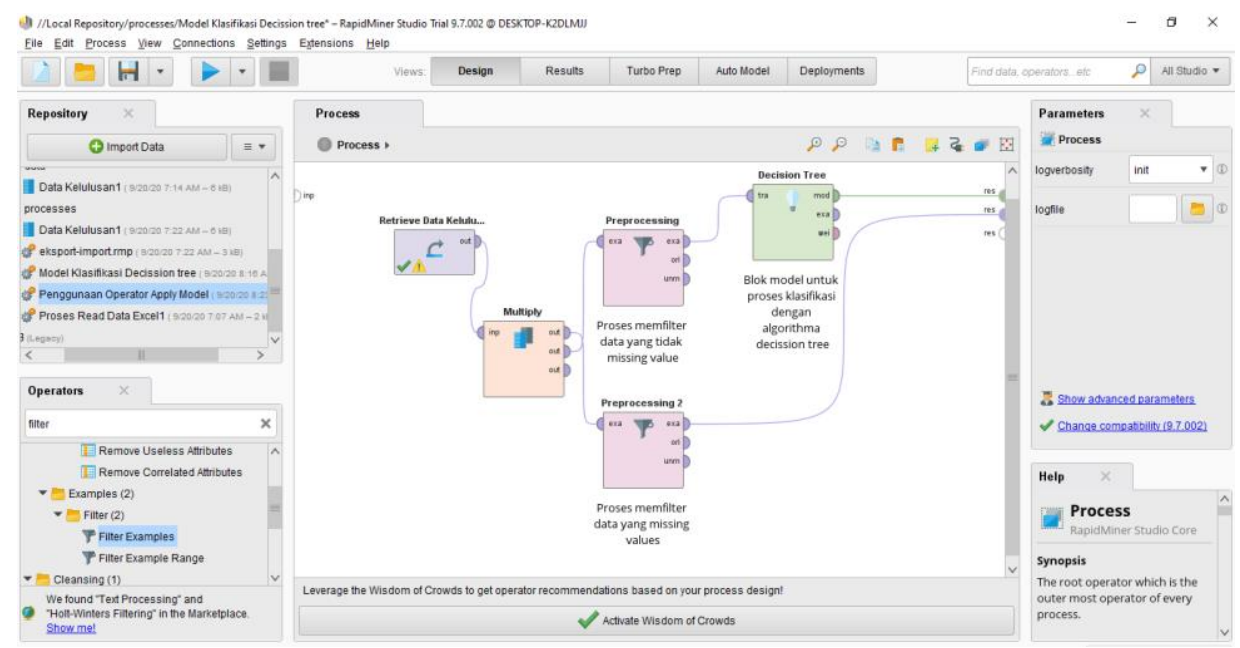


Penggunaan Metode Decision Tree untuk Mendeteksi Keterlambatan Masa Studi Mahasiswa Diperguruan Tinggi Brebes

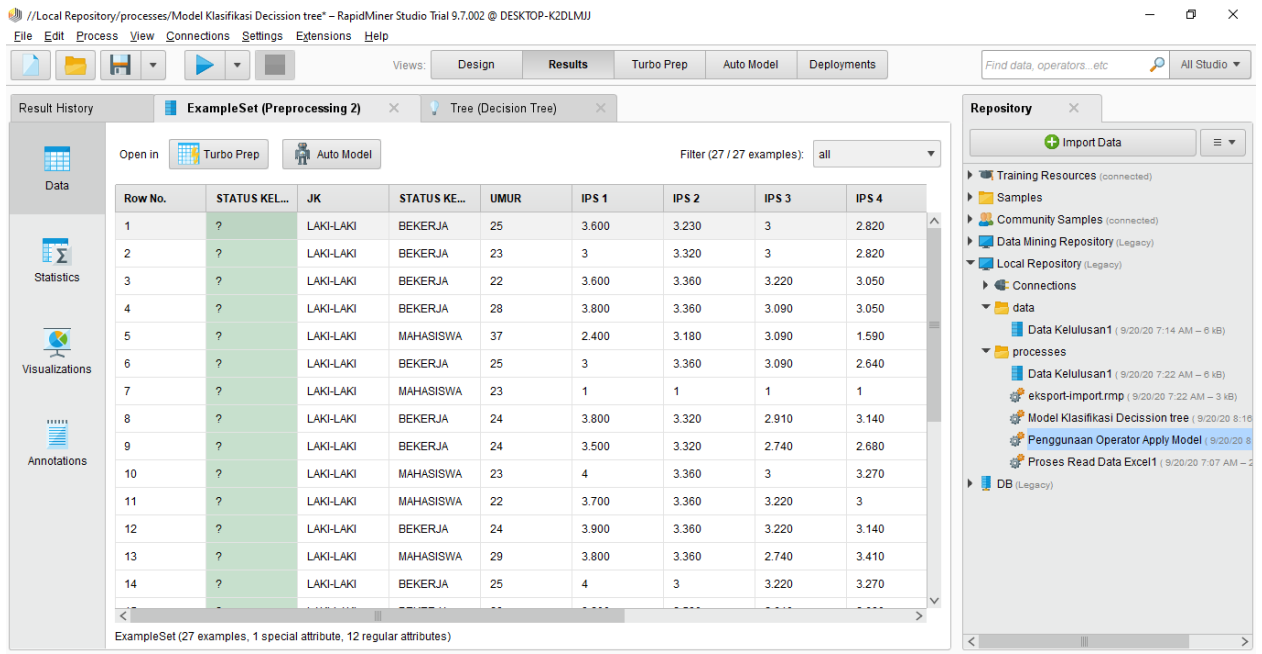

\section{Gambar 4}

Membuat blok model prediksi sebagai data testing

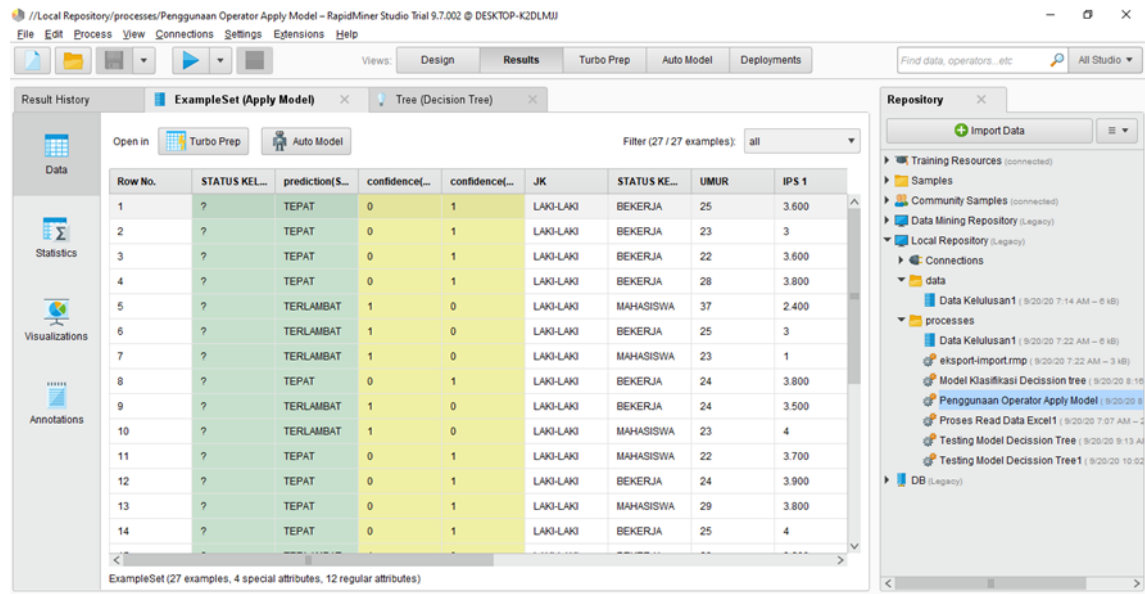

\section{Gambar 5}

Hasil data setelah di testing

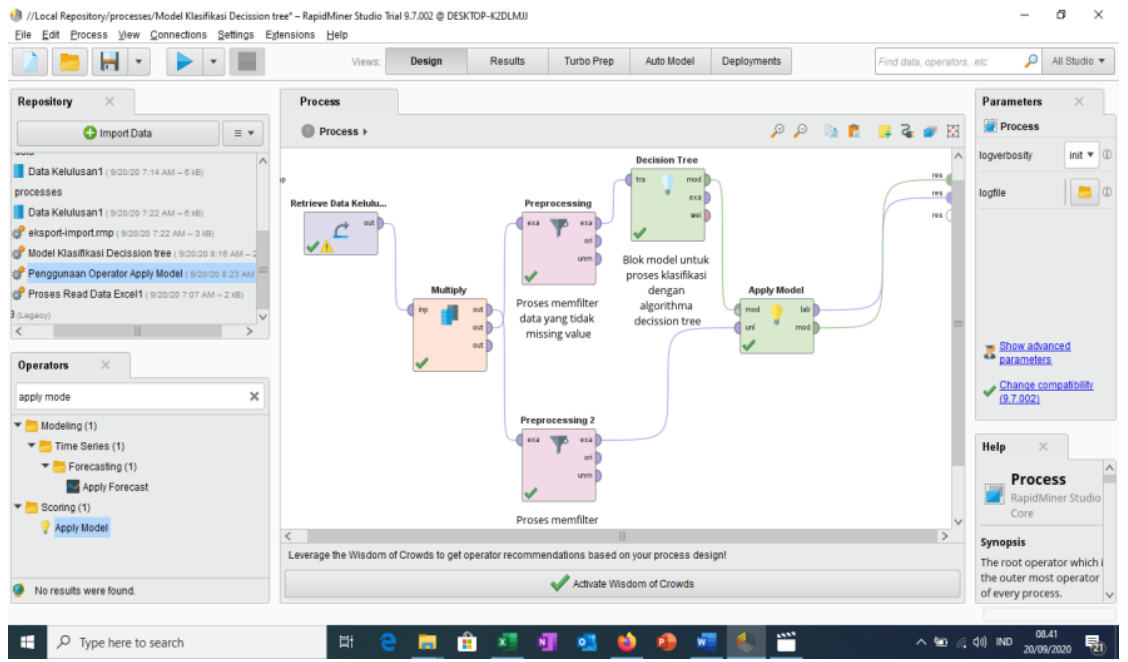


Nur Ariesanto Ramdhan, Abdul Khamid

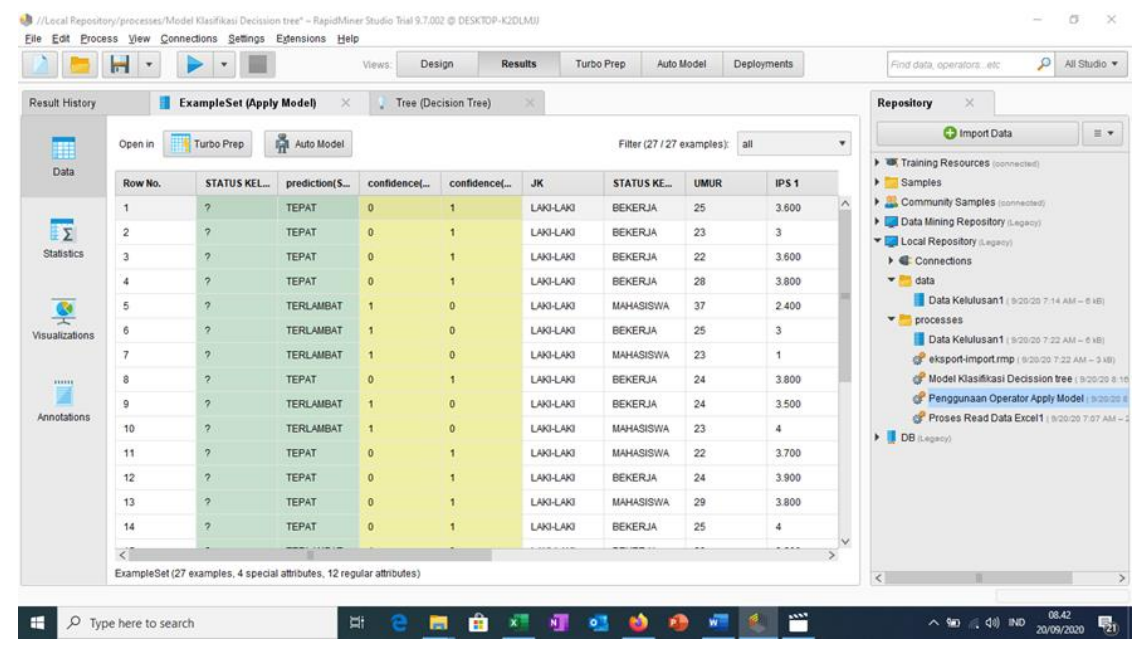

Gambar 6

Data Hasil Prediksi

Tabel 2

Data Hasil Prediksi

\begin{tabular}{|c|c|c|c|c|c|c|c|c|c|c|c|c|}
\hline JK & $\begin{array}{l}\text { STATUS } \\
\text { KERJA }\end{array}$ & UMUR & $\begin{array}{c}\text { IPS } \\
1 \\
\end{array}$ & $\begin{array}{c}\text { IPS } \\
\mathbf{2} \\
\end{array}$ & $\begin{array}{c}\text { IPS } \\
\mathbf{3} \\
\end{array}$ & $\begin{array}{c}\text { IPS } \\
4 \\
\end{array}$ & $\begin{array}{c}\text { IPS } \\
5 \\
\end{array}$ & $\begin{array}{c}\text { IPS } \\
6 \\
\end{array}$ & $\begin{array}{c}\text { IPS } \\
7 \\
\end{array}$ & $\begin{array}{c}\text { IPS } \\
8 \\
\end{array}$ & IPK & $\begin{array}{c}\text { prediction(STATUS } \\
\text { KELULUSAN) } \\
\end{array}$ \\
\hline LAKI-LAKI & BEKERJA & 25,0 & 3,6 & 3,2 & 3,0 & 2,8 & 3,1 & 2,7 & 2,9 & 0,0 & 2,7 & TEPAT \\
\hline LAKI-LAKI & BEKERJA & 23,0 & 3,0 & 3,3 & 3,0 & 2,8 & 3,2 & 2,3 & 3,0 & 0,0 & 2,6 & TEPAT \\
\hline LAKI-LAKI & BEKERJA & 22,0 & 3,6 & 3,4 & 3,2 & 3,1 & 3,3 & 3,0 & 3,0 & 0,0 & 2,8 & TEPAT \\
\hline LAKI-LAKI & BEKERJA & 28,0 & 3,8 & 3,4 & 3,1 & 3,1 & 2,6 & 3,0 & 3,0 & 0,0 & 2,7 & TEPAT \\
\hline LAKI-LAKI & MAHASISWA & 37,0 & 2,4 & 3,2 & 3,1 & 1,6 & 2,9 & 2,0 & 2,1 & 0,0 & 2,2 & TERLAMBAT \\
\hline LAKI-LAKI & BEKERJA & 25,0 & 3,0 & 3,4 & 3,1 & 2,6 & 1,0 & 0,1 & 0,6 & 0,0 & 1,7 & TERLAMBAT \\
\hline LAKI-LAKI & MAHASISWA & 23,0 & 1,0 & 1,0 & 1,0 & 1,0 & 1,0 & 1,0 & 1,0 & 0,0 & 0,9 & TERLAMBAT \\
\hline LAKI-LAKI & BEKERJA & 24,0 & 3,8 & 3,3 & 2,9 & 3,1 & 3,1 & 2,2 & 2,9 & 0,0 & 2,7 & TEPAT \\
\hline LAKI-LAKI & BEKERJA & 24,0 & 3,5 & 3,3 & 2,7 & 2,7 & 0,6 & 1,6 & 0,9 & 0,0 & 1,9 & TERLAMBAT \\
\hline LAKI-LAKI & MAHASISWA & 23,0 & 4,0 & 3,4 & 3,0 & 3,3 & 3,4 & 2,1 & 0,1 & 0,0 & 2,4 & TERLAMBAT \\
\hline LAKI-LAKI & MAHASISWA & 22,0 & 3,7 & 3,4 & 3,2 & 3,0 & 2,8 & 2,8 & 2,9 & 0,0 & 2,7 & TEPAT \\
\hline LAKI-LAKI & BEKERJA & 24,0 & 3,9 & 3,4 & 3,2 & 3,1 & 2,9 & 2,4 & 2,6 & 0,0 & 2,7 & TEPAT \\
\hline LAKI-LAKI & MAHASISWA & 29,0 & 3,8 & 3,4 & 2,7 & 3,4 & 3,2 & 2,4 & 2,7 & 0,0 & 2,7 & TEPAT \\
\hline LAKI-LAKI & BEKERJA & 25,0 & 4,0 & 3,0 & 3,2 & 3,3 & 3,2 & 2,3 & 3,3 & 0,0 & 2,8 & TEPAT \\
\hline LAKI-LAKI & BEKERJA & 28,0 & 3,2 & 2,6 & 2,6 & 2,7 & 2,9 & 3,0 & 2,6 & 0,0 & 2,4 & TERLAMBAT \\
\hline LAKI-LAKI & BEKERJA & 26,0 & 3,5 & 3,5 & 3,1 & 3,3 & 3,1 & 3,1 & 3,1 & 0,0 & 2,8 & TEPAT \\
\hline LAKI-LAKI & BEKERJA & 30,0 & 3,3 & 2,3 & 2,7 & 2,0 & 0,3 & 0,8 & 1,0 & 0,0 & 1,5 & TERLAMBAT \\
\hline LAKI-LAKI & BEKERJA & 36,0 & 2,9 & 1,9 & 3,2 & 3,3 & 3,2 & 2,3 & 3,3 & 0,0 & 2,5 & TEPAT \\
\hline LAKI-LAKI & BEKERJA & 38,0 & 3,0 & 3,0 & 3,0 & 3,0 & 3,5 & 2,8 & 3,1 & 0,0 & 2,7 & TEPAT \\
\hline LAKI-LAKI & MAHASISWA & 26,0 & 4,0 & 3,5 & 3,5 & 3,1 & 3,3 & 3,1 & 3,7 & 0,0 & 3,0 & TEPAT \\
\hline LAKI-LAKI & BEKERJA & 27,0 & 3,0 & 3,0 & 3,0 & 3,0 & 3,6 & 2,9 & 3,2 & 0,0 & 2,7 & TEPAT \\
\hline LAKI-LAKI & MAHASISWA & 24,0 & 0,9 & 1,6 & 2,4 & 1,0 & 0,2 & 1,0 & 1,0 & 0,0 & 1,0 & TERLAMBAT \\
\hline LAKI-LAKI & MAHASISWA & 27,0 & 0,1 & 1,0 & 1,0 & 1,0 & 1,0 & 1,0 & 1,0 & 0,0 & 0,8 & TERLAMBAT \\
\hline LAKI-LAKI & BEKERJA & 45,0 & 3,6 & 3,4 & 3,1 & 2,7 & 2,7 & 2,3 & 3,0 & 0,0 & 2,6 & TEPAT \\
\hline LAKI-LAKI & BEKERJA & 26,0 & 3,0 & 3,0 & 3,0 & 3,0 & 3,6 & 2,9 & 3,2 & 0,0 & 2,7 & TEPAT \\
\hline LAKI-LAKI & BEKERJA & 27,0 & 3,5 & 3,5 & 3,1 & 3,3 & 3,1 & 3,1 & 3,1 & 0,0 & 2,8 & TEPAT \\
\hline LAKI-LAKI & BEKERJA & 26,0 & 3,0 & 3,0 & 3,0 & 3,0 & 3,6 & 2,9 & 3,2 & 0,0 & 2,7 & TEPAT \\
\hline
\end{tabular}




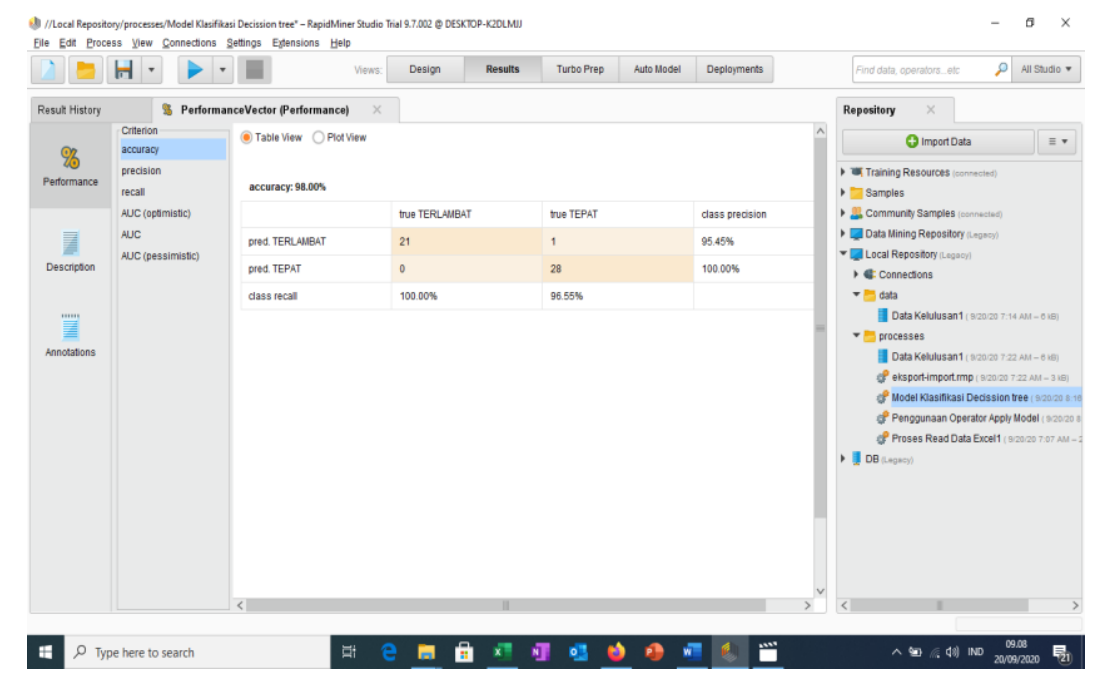

Gambar 7

Tingkat keakurasian data dalam prediksi (\%)

Pengujian di ukur dengan menggunakan confussion matrix untuk mengukur performa klasifikasi dengan menggunakan dua kelas yaitu tepat dan terlambat.

Tingkat accuracy : $98.00 \%$.

Tabel 3

Prediksi

\begin{tabular}{lccc}
\hline \multirow{2}{*}{ Klasifikasi C45 } & \multicolumn{3}{c}{ Prediksi } \\
\cline { 2 - 4 } & True Terlambat & True Tepat & Class precision \\
\hline Terlambat & 21 & 1 & $95.45 \%$ \\
\hline Tepat & 0 & 28 & $100 \%$ \\
\hline Class recall & $100 \%$ & $96.55 \%$ & \\
\hline
\end{tabular}

\section{Kesimpulan}

Penulis menggunakan satu special atribut (status kelulusan) dan duabelas regular atribut ((JK, Status Kerja, Umur, IPS $(1,2,3,4,5,6,7,8)$ dan IPK)), data set KHS mahasiswa tahun 2014-2015 dan 2015-2016, data testing tahun 2016-2017, software rapidminer-studio-9.7.2. menggunakan algoritma decision tree $\mathrm{C} 4.5$ dengan output yang terbentuk ialah klasifkasi berupa pohon keputusan (decision tree). Algortitma C4.5 terbukti dapat digunakan dalam memprediksi atau mengkalisifikasi masa studi mahasiswa dengan evaluasi penelitian tingkat nilai akurasi sebanyak $98.00 \%$, dengan presisi terlambat $95.45 \%$ dan tepat $100 \%$, Class recall terlambat $100 \%$, dan recall tepat 96.55\%. Pengujian dengan rapidminer terbukti efektif dan fleksibel dengan hasil perhitungan yang tepat. 


\section{BIBLIOGRAFI}

Abu Tair, Mohammed M., \& El-Halees, Alaa M. (2012). Mining educational data to improve students' performance: a case study. International Journal of Information, 2(2). Google Scholar

Harianto, Didi Rosiyadi, \& Rosiyadi, Didi. (2020). Komparasi Algortima C4. 5, Naïve Bayes, dan k-Nearest Neighbor Sebagai Sistem Pendukung Keputusan Menaikkan Jumlah Peserta Didik. Jurnal Informatika, 7(1). Google Scholar

Jaedun, Amat. (2011). Metodologi penelitian eksperimen. Fakultas Teknik UNY, 12. Google Scholar

Kamagi, David Hartanto, \& Hansun, Seng. (2014). Implementasi Data Mining dengan Algoritma C4. 5 untuk Memprediksi Tingkat Kelulusan Mahasiswa. Ultimatics: Jurnal Teknik Informatika, 6(1), 15-20. Google Scholar

Nofriansyah, Dicky, Kom, S., \& Kom, M. (2015). Konsep data mining Vs Sistem pendukung keputusan. Deepublish. Google Scholar

Rahman, Ade Fatma Ayu. (2020). Prediksi Kelulusan Mahasiswa Menggunakan Algoritma C4. 5 (Studi Kasus Di Universitas Peradaban). Indonesian Journal of Informatics and Research, 1(2), 70-77. Google Scholar

Rismayanti, Rismayanti. (2018). Decision Tree Penentuan Masa Studi Mahasiswa Prodi Teknik Informatika (Studi Kasus: Fakultas Teknik dan Komputer Universitas Harapan Medan). Query: Journal of Information Systems, 2(1). Google Scholar

Romero, Cristóbal, \& Ventura, Sebastián. (2010). Educational data mining: a review of the state of the art. IEEE Transactions on Systems, Man, and Cybernetics, Part $C$ (Applications and Reviews), 40(6), 601-618. Google Scholar

Rosandy, Triowali. (2016). Perbandingan Metode Naive Bayes Classifier Dengan Metode Decision Tree (C4. 5) Untuk Menganalisa Kelancaran Pembiayaan (Study Kasus: KSPPS/BMT Al-Fadhila. Jurnal Teknologi Informasi Magister, 2(01), 5262. Google Scholar

Siregar, Amril Mutoi, Kom, S., Puspabhuana, M. Kom D. A. N. Adam, Kom, S., \& Kom, M. (2017). Data Mining: Pengolahan Data Menjadi Informasi dengan RapidMiner. CV Kekata Group. Google Scholar

Sutabri, Tata. (2012). Analisis sistem informasi. Penerbit Andi. Google Scholar

Yadav, Surjeet Kumar, \& Pal, Saurabh. (2012). Data mining: A prediction for performance improvement of engineering students using classification. ArXiv Preprint ArXiv:1203.3832. Google Scholar

\section{Copyright holder:}


Penggunaan Metode Decision Tree untuk Mendeteksi Keterlambatan Masa Studi Mahasiswa Diperguruan Tinggi Brebes

Nur Ariesanto Ramdhan, Abdul Khamid (2021)

First publication right:

Syntax Literate: Jurnal Ilmiah Indonesia

This article is licensed under:

(c) (i) (?) 